\title{
The Carotenoid Pigments of Mycoplasma
}

\author{
BY P. F. SMITH \\ Department of Microbiology, School of Medicine, University of South Dakota, \\ Vermillion, U.S.A.
}

(Received 21 June 1962)

\begin{abstract}
SUMMARY
All the Mycoplasma organisms examined, which did not require a sterol as a nutrient, contained a carotenoid pigment identifiable as the hydrocarbon, neurosporene, and a carotenol. The carotenol occurred as the free alcohol, esterified with fatty acids, and in glycosidic linkage with glucose. The carotenyl glucoside in two organisms was hydrolysable with $\beta$-glucosidase, indicating the glucosidic linkage to be in the $\beta$ configuration. The carotenoid compounds found in these organisms are analogous to the sterol compounds found in sterol-requiring organisms. Cholesterol supplied in the culture medium spared the synthesis of the carotenoids. Carotenols are postulated to serve in reactions which involve substrate transport and end-product transport across the cell membrane.
\end{abstract}

\section{INTRODUCTION}

Organisms of the Mycoplasma group which require sterol as nutrient are incapable of synthesis of their non-saponifiable lipids (Smith \& Rothblat, 1962) and incorporate sterols of appropriate molecular configuration without structural alteration (Rothblat \& Smith, 1961; Smith, 1962). Organisms of this group which do not require sterol as nutrient synthesize their non-saponifiable lipids from acetate or mevalonate (Smith \& Rothblat, 1962). However, when supplied with cholesterol, these latter organisms incorporate it in the same fashion as do the sterol-requiring organisms. The non-saponifiable lipids of both types of organisms are found primarily in the insoluble fraction (cell membrane) following sonic treatment. The sterol of those organisms incapable of carbohydrate utilization occurs as free alcohol and as esters of fatty acids, and of those organisms which are capable of carbohydrate utilization also in $\beta$-glycosidic linkage with glucose (Rothblat \& Smith, 1961). Since the requirement for sterol as nutrient has been advanced as a criterion for classification of the pleuropneumonia group of organisms (Edward \& Freundt, 1956), although some organisms encompassed in this schema have no sterol requirement as nutrient, some analogy with the non-saponifiable lipid fraction of these two types of Mycoplasma was sought. Identification of all the components of the non-saponifiable lipid fraction of several non-sterol requiring strains was considered a necessary step in proving or disproving the theory that non-saponifiable lipids are concerned with maintenance of the structural integrity of the cell and are involved in substrate and end product transfer across the cell membrane (Smith, 1959; Smith, 1960; Rothblat \& Smith, 1961).

Vol. 32, No. 2 roas issued 21 August 1963 


\section{METHODS}

Organisms. Mycoplasma laidlawii strain B was originally obtained from Dr D. G. ff. Edward (Wellcome Research Laboratories, Beckenham, Kent, England) and has been maintained in these laboratories. $M$. laidlawii strain A, $\boldsymbol{M}$. inocuum sp.nov. (Adler, Shifrine \& Ortmayer, 1961) and an unclassified strain kHs of caprine origin were kindly supplied by Dr M. Shifrine (University of California, Davis, California).

Media. A basal medium composed of $2 \%$ Bacto tryptose and $0.5 \% \mathrm{NaCl}$ was used. This basal medium was supplemented with $0.5 \%$ Bacto PPLO serum fraction (medium A), $0.5 \%$ glucose (medium B), $0.5 \%$ sodium acetate (medium C), $0.5 \%$ glucose $+0.5 \%$ sodium acetate (medium D) or $0.5 \%$ glucose $+0.5 \%$ sodium acetate $+0.5 \%$ Bacto PPLO serum fraction (medium $\mathrm{E}$ ) for the determination of the culture medium which gave optimal yields of highly pigmented organisms. Initiation of growth in the basal liquid medium with an inoculum from solid medium $(0.3 \%$ beef extract $+0.5 \%$ tryptose $+0.5 \%$ sodium chloride $+1.5 \%$ agar, $\mathrm{pH} \mathbf{8} \cdot \mathbf{0})$ required addition of $\mathbf{0 . 5} \%$ Bacto PPLO serum fraction $+0.5 \%$ glucose. Once growth was initiated in liquid medium, Bacto PPLO serum fraction was no longer required. Experiments designed to demonstrate the sparing effect of sterol on the synthesis of non-saponifiable lipids used culture medium D supplemented with different concentrations of Bacto PPLO serum fraction and $10 \mu \mathrm{c}$. sodium acetate${ }^{1-14} \mathrm{C}$.

Cultivation. Experiments designed to determine the culture medium which gave optimal growth used cultures of 21 . volume. Growth of organisms in quantity sufficient for isolation and analysis of non-saponifiable lipids required the use of 10-60 l. medium inoculated in batches of 2 or 5 l. Cultures were incubated statically at $37^{\circ}$. The organisms were harvested and washed as previously described (Smith, 1955). Incubated uninoculated culture medium contained no sedimentable material.

Extraction procedures. Methods used for extraction of total lipids, saponification and isolation of the non-saponifiable lipid fraction were given in a previous report (Rothblat \& Smith, 1961). Fatty acid fractions derived from the carotenyl ester fractions were extracted from the aqueous layer at $\mathrm{pH} 4$ with 3 vol. diethyl ether. Following removal of the ether in vacuo and neutralization with $\mathrm{NaOH}$, the extracted acids were distilled at $\mathrm{pH} \mathrm{4,} \mathrm{volatile} \mathrm{acids} \mathrm{being} \mathrm{collected} \mathrm{in} \mathrm{standard}$ alkali. Residual non-volatile acids were re-extracted with diethyl ether and titrated with standard alkali. Volatile fatty acid fractions were re-extracted, neutralized with ammonia and used for paper chromatographic analysis.

Chromatographic procedures. Chromatography of the non-saponifiable lipid fractions was conducted on $3 \mathrm{~g}$. activated silicic acid (Unisil, 100-200 mesh, Clarkson Chemical Co., Inc., Williamsport, Pa., U.S.A.) packed in a column $10 \mathrm{~cm}$. in diameter. Non-saponifiable lipid or total lipid fractions in amounts of 10-100 mg. were added to the column with two or three $5 \mathrm{ml}$. lots of light petroleum (b.p. $30^{\circ}-60^{\circ}$ ). The series of eluting solvents were modifications of those described by Hirsch \& Ahrens (1958). For separation of the components of the non-saponifiable lipid fractions this series consisted of (1) $50 \mathrm{ml} .1 \%(\mathrm{v} / \mathrm{v})$ diethyl ether in light petroleum (b.p. $\left.30^{\circ}-60^{\circ}\right)$; (2) $100 \mathrm{ml} .4 \%$ (v/v) diethyl ether in light petroleum (b.p. $30^{\circ}-60^{\circ}$ ); (3) $100 \mathrm{ml} .8 \%(\mathrm{v} / \mathrm{v})$ diethyl ether in light petroleum (b.p. $30^{\circ}-60^{\circ}$ ); (4) $100 \mathrm{ml}$. 
$25 \%(\mathrm{v} / \mathrm{v})$ diethyl ether in light petroleum (b.p. $\left.30^{\circ}-60^{\circ}\right)$; (5) $100 \mathrm{ml}$. diethyl ether; (6) $50 \mathrm{ml}$. anhydrous methanol. Separation of the carotenoid pigments in the total lipid fraction was accomplished with the following series of solvent mixtures: (1) $100 \mathrm{ml} .1 \%(\mathrm{v} / \mathrm{v})$ benzene in light petroleum (b.p. $30^{\circ}-60^{\circ}$ ); (2) $300 \mathrm{ml}$. $2 \%(\mathrm{v} / \mathrm{v})$ benzene in light petroleum (b.p. $\left.30^{\circ}-60^{\circ}\right) ;(3) 50 \mathrm{ml} .8 \%(\mathrm{v} / \mathrm{v})$ diethyl ether in light petroleum (b.p. $\left.30^{\circ}-60^{\circ}\right) ;(4) 50 \mathrm{ml} .25 \%(\mathrm{v} / \mathrm{v})$ diethyl ether in light petroleum (b.p. $30^{\circ}-60^{\circ}$ ); (5) $50 \mathrm{ml}$. diethyl ether. Five ml. samples of effluent were collected by gravity flow, in a fraction collector. Solvents were removed in vacuo and tubes containing visible residues were immediately placed under nitrogen or analysed spectrophotometrically. Chromatography of the volatile acids was performed by the method of Reid \& Lederer (1951).

Radioisotope counting. ${ }^{14}$ Carbon counting was performed as previously described (Smith \& Rothblat, 1960) except for the use of a Tracerlab Model SC-70 scaler coupled with a Model SC-50 B automatic flow counter and Model SC-88 computer with print-out.

Analytical procedures. Spectrophotometric measurements were carried out in a Beckman Model DU spectrophotometer, Beckman Model DB recording spectrophotometer, or in a Bausch and Lomb Spectronic 505 recording spectrophotometer. Carotenoids were detected by the Carr-Price reaction (Hawk, Oser \& Summerson, 1947) and reducing sugar by the method of Park \& Johnson (1949). Acid hydrolysis of non-saponifiable lipids was carried out according to the method of Swift (1952). A determination of pigment synthesized was made by measurement of absorption of the total lipid extract in a volume of $5 \mathrm{ml}$. of dimethoxymethane (methylal) + methanol ( $4+1$, by vol.) in the Klett-Summerson photometer with a $420 \mathrm{~m} \mu$ filter. Iodine-catalysed photoisomerizations of the carotenoid pigments were carried out by the method described by Magoon \& Zechmeister (1957). All other chemical and physical procedures have been described previously (Rothblat \& Smith, 1961).

Enzymic analyses. Pigments in amounts of about $1 \mathrm{mg}$. containing chemically detectable reducing sugar were taken up in $0.1 \mathrm{ml}$. warm ethanol. To this solution was added $2 \mathrm{mg}$. $\beta$-glucosidase (almond emulsin, Nutritional Biochemicals Corp. Cleveland, Ohio, U.S.A.) and $\mathbf{0 . 0 6 7} \mathrm{M}$-phosphate buffer $(\mathrm{pH} \mathbf{7 \cdot 0}$ ) to a total volume of $1.5 \mathrm{ml}$. A control without substrate but containing $0.1 \mathrm{ml}$. ethanol was run. After $3 \mathrm{hr}$. at $37^{\circ}, \mathbf{1 . 5} \mathrm{mg}$. adenosine triphosphate (sodium salt), 1.5 mg. hexokinase and $0.067 \mathrm{M}$-phosphate buffer $(\mathrm{pH} \mathrm{7.5})$ to a final volume of $3.0 \mathrm{ml}$. were added and the mixture re-incubated for $1 \mathrm{hr}$. at $37^{\circ}$. To $0.5 \mathrm{ml}$. portions of the reaction mixtures were added $1.5 \mathrm{mg}$. glucose-6-phosphate dehydrogenase, $1.5 \mathrm{mg}$. nicotinamideadenine dinucleotidephosphate (NADP), and 0.067 M-phosphate buffer $(\mathrm{pH} \mathrm{7.5)}$ to a total volume of $\mathbf{3 . 0} \mathrm{ml}$. Reduction of NADP was followed spectrophotometrically at $340 \mathrm{~m} \mu$. In instances where no hydrolysis occurred in the presence of $\beta$-glucosidase, the aqueous layer, following acid hydrolysis of the pigment and freed from $\mathrm{SO}_{4}^{2-}$ by precipitation with $\mathrm{Ba}(\mathrm{OH})_{2}$, was used as the substrate, omitting the step involving $\beta$-glucosidase.

Chemicals. All reagents and enzymes were of the highest purity commercially available. Sodium acetate- $1-{ }^{14} \mathrm{C}$ with a specific activity of $4 \mathrm{mc} . / \mathrm{m}$-mole and acetic${ }^{1-14} \mathrm{C}$ anhydride with a specific activity of $2.73 \mathrm{mc} . / \mathrm{m}$-mole were obtained from Nuclear Chicago Corporation (Chicago, Illinois, U.S.A.). 


\section{RESULTS}

The necessity for obtaining optimal yields of highly pigmented organisms to permit characterization of the carotenoid pigments required the preliminary determination of the best conditions for growth. Aeration had been shown previously to decrease the pigmentation of the organisms (Rothblat \& Smith, 1961). All four organisms were grown in five different culture media (media $\mathbf{A}$ to $\mathbf{E}$ as described under Methods). Table 1 presents the data on total lipids and the pigment produced/mg. dry wt. organism. The presence of cholesterol (media A and E) resulted in a decrease in amount of total lipid and pigments. Glucose or sodium acetate as the sole supplement permitted only suboptimal pigment production. Best results were achieved with medium $\mathbf{D}$ which was therefore selected for the growth of large batches of organisms.

Table 1. Effect of supplements to culture medium on total lipids and carotenoid pigment production in four strains of Mycoplasma

\begin{tabular}{|c|c|c|c|c|c|c|}
\hline \multirow{2}{*}{$\begin{array}{l}\text { Mycoplasma } \\
\text { species }\end{array}$} & \multirow{2}{*}{$\begin{array}{c}\text { Cell } \\
\text { fraction }\end{array}$} & \multicolumn{5}{|c|}{ Culture medium* } \\
\hline & & $\mathbf{A}$ & B & $\mathbf{C}$ & D & $\mathbf{E}$ \\
\hline $\begin{array}{l}\text { M. laidlawii, } \\
\text { strain A }\end{array}$ & $\begin{array}{l}\text { Cell yield } \dagger \\
\text { Total lipid } \$ \\
\text { Pigment\$ }\end{array}$ & $\begin{array}{l}59 \cdot 6 \\
0 \cdot 07 \\
0 \cdot 0036\end{array}$ & $\begin{array}{l}25 \cdot 5 \\
0 \cdot 24 \\
0 \cdot 0094\end{array}$ & $\begin{array}{l}34 \cdot 1 \\
0 \cdot 13 \\
0 \cdot 0175\end{array}$ & $\begin{array}{l}38 \cdot 1 \\
0 \cdot 12 \\
0 \cdot 0122\end{array}$ & $\begin{array}{l}57 \cdot 5 \\
0.06 \\
0 \cdot 0076\end{array}$ \\
\hline $\begin{array}{l}\text { M. laidlazeii, } \\
\text { strain B }\end{array}$ & $\begin{array}{l}\text { Cell yield } \dagger \\
\text { Total lipid } \\
\text { Pigment }\end{array}$ & $\begin{array}{l}15 \cdot 7 \\
0 \cdot 14 \\
0 \cdot 0049\end{array}$ & $\begin{array}{l}14 \cdot 3 \\
0 \cdot 22 \\
0 \cdot 0237\end{array}$ & $\begin{array}{l}12 \cdot 0 \\
0 \cdot 28 \\
0 \cdot 0871\end{array}$ & $\begin{array}{l}18 \cdot 2 \\
0 \cdot 27 \\
0 \cdot 0817\end{array}$ & $\begin{array}{l}37 \cdot 8 \\
0 \cdot 13 \\
0 \cdot 0172\end{array}$ \\
\hline $\boldsymbol{M}$. inосиит & $\begin{array}{l}\text { Cell yield } \\
\text { Total lipid } \\
\text { Pigment }\end{array}$ & $\begin{array}{l}39 \cdot 8 \\
0 \cdot 066 \\
0 \cdot 0074\end{array}$ & $\begin{array}{l}26 \cdot 0 \\
0 \cdot 084 \\
0 \cdot 0138\end{array}$ & $\begin{array}{l}21 \cdot 8 \\
0 \cdot 068 \\
0 \cdot 0286\end{array}$ & $\begin{array}{l}17 \cdot 5 \\
0 \cdot 138 \\
0 \cdot 0474\end{array}$ & $\begin{array}{l}67 \cdot 6 \\
0 \cdot 064 \\
0 \cdot 0065\end{array}$ \\
\hline Caprine strain KHs & $\begin{array}{l}\text { Cell yield } \\
\text { Total lipid } \\
\text { Pigment }\end{array}$ & $\begin{array}{l}63 \cdot 5 \\
0.074 \\
0.0033\end{array}$ & $\begin{array}{l}25 \cdot 5 \\
0 \cdot 136 \\
0 \cdot 0071\end{array}$ & $\begin{array}{l}40 \cdot 9 \\
0 \cdot 083 \\
0 \cdot 0092\end{array}$ & $\begin{array}{l}41 \cdot 7 \\
0 \cdot 147 \\
0 \cdot 0163\end{array}$ & $\begin{array}{l}53.8 \\
0.082 \\
0.0041\end{array}$ \\
\hline $\begin{array}{l}* \\
\dagger \\
\ddagger \\
\S\end{array}$ & $\begin{array}{l}\text { lture media } \\
\text { dry wt./. } \\
\text { total lipid/s } \\
\text { tical density }\end{array}$ & $\begin{array}{l}\text { ribed in } \\
\text { dry wt. } \\
420 \mathrm{~m} \mu / 1\end{array}$ & $\begin{array}{l}\text { ethods. } \\
\text { lls. } \\
\text { dry wt. }\end{array}$ & & & \\
\hline
\end{tabular}

A further attempt to demonstrate the sparing effect of cholesterol on the synthesis of carotenoid pigments was made by measuring the incorporation of acetate${ }^{1-14} \mathrm{C}$ into the non-saponifiable lipid fraction. Bacto PPLO serum fraction containing 80-100 $\mu \mathrm{g}$. cholesterol $/ \mathrm{ml}$. was the source of sterol supplied to the culture medium. Only one organism, Mycoplasma laidlawii, strain в, was used. Table 2 presents the data of this experiment. Increasing amounts of available sterol brought about decreasing synthesis of carotenoid pigments and decreasing incorporation of acetate-1-14C into the non-saponifiable lipid fraction.

Column chromatography of the non-saponifiable lipid fraction of each of the four organisms resulted in the separation of three pigmented bands. The first band, pigment $\mathbf{A}$, was eluted with $1 \%(\mathrm{v} / \mathrm{v})$ diethyl ether in light petroleum (b.p. $30^{\circ}-$ $\left.60^{\circ}\right)$; the second band, pigment $B$, with $25 \%(v / v)$ diethyl ether in light petroleum b.p. $30^{\circ}-60^{\circ}$ ); the third band, pigment $\mathrm{C}$, with diethyl ether. Stripping of the 
column with methanol resulted in the elution of additional material, especially when the total lipid fractions were chromatographed. No analyses were performed on the methanol fractions except examination of the absorption spectra which revealed nothing significant as regards carotenoids. It was not possible to crystallize any of the pigments, primarily because of the small amounts available. Further chromatography on silicic acid columns with gradient elution technique did not separate any of the three pigmented fractions into additional components. The ratios of weight of the different pigments varied from experiment to experiment but invariably the relative proportions were $\mathrm{C}>\mathrm{B}>\mathrm{A}$. Table 3 presents results of representative experiments.

Table 2. Sparing action of cholesterol on synthesis of non-saponifiable lipids by Mycoplasma laidlawii, strain $\mathrm{B}$

$\begin{array}{ccc}\begin{array}{c}\text { Difco PPLO } \\ \text { serum fraction } \\ \text { (cholesterol source) } \\ (\%)\end{array} & \text { Pigments* } & \text { Radioactivity† } \\ \text { None } & 0.014 & 169 \\ 0.05 & 0.012 & 184 \\ 0.10 & 0.011 & 166 \\ 0.50 & 0.010 & 119 \\ 1.00 & 0.009 & 63\end{array}$

* Optical density/mg. dry wt. cells; † counts/min./mg. non-saponifiable lipid.

Table 3. Ratios of weights of carotenoid pigments from various Mycoplasma species

\begin{tabular}{|c|c|c|c|}
\hline \multirow[b]{2}{*}{ Mycoplasma species } & \multicolumn{3}{|c|}{ Pigment } \\
\hline & $\begin{array}{c}\text { A } \\
\text { (hydro- } \\
\text { carbon) }\end{array}$ & $\begin{array}{c}\text { B } \\
\text { (hydroxy- } \\
\text { lated) }\end{array}$ & $\begin{array}{c}\mathrm{C} \\
\text { (gluco- } \\
\text { side) }\end{array}$ \\
\hline M. laidlawii, strain в & $1 \cdot 0$ & $2 \cdot 5$ & $12 \cdot 4$ \\
\hline M. inocuum & $1 \cdot 0$ & $1 \cdot 8$ & $\mathbf{2 \cdot 2}$ \\
\hline Caprine strain кHS & $1 \cdot 0$ & $2 \cdot 1$ & $5 \cdot 9$ \\
\hline
\end{tabular}

Pigment A was a brilliant yellow and imparted most of the colour to the sedimented organisms. Exposure of this pigment to air even for a short time resulted in a decrease of the colour intensity. Such changes are common to carotenoid pigments in solution and occur as a result of isomerization from the all trans isomer to a mixture of the trans and cis isomers followed by oxidative destruction (Deuel, 1951). Thus chemical and physical analyses on pigment $\mathrm{A}$ were made immediately upon recovery from the column. When stored it was held dry in an atmosphere of nitrogen. Table 4 lists the data describing the properties of pigment $\mathbf{A}$ from each of the four organisms. Figure 1 shows the absorption spectra of these pigments. The non-polarity of these pigments, their absorption spectra and coefficients support the supposition that they are hydrocarbons of carotenoid nature. The absorption maxima of this pigment from all four organisms and the absorption coefficients of pigment from two organisms, Mycoplasma laidlawii, strains $\mathbf{A}$ and $\mathbf{B}$, are almost identical to the values for neurosporene (Haxo, 1949). 
Identification of pigment A from Mycoplasma laidlawii, strain B, as neurosporene, was made by comparing it with authentic neurosporene isolated from commercial tomato paste and kindly supplied by Dr J. W. Porter (Veterans Administration Hospital, Madison, Wisconsin, U.S.A.). The spectral characteristics of the authentic neurosporene, pigment $\mathbf{A}$, and a mixture of the two, are shown in Table 5 . The mixture was subjected to chromatography on a silicic acid (Unisil) column with

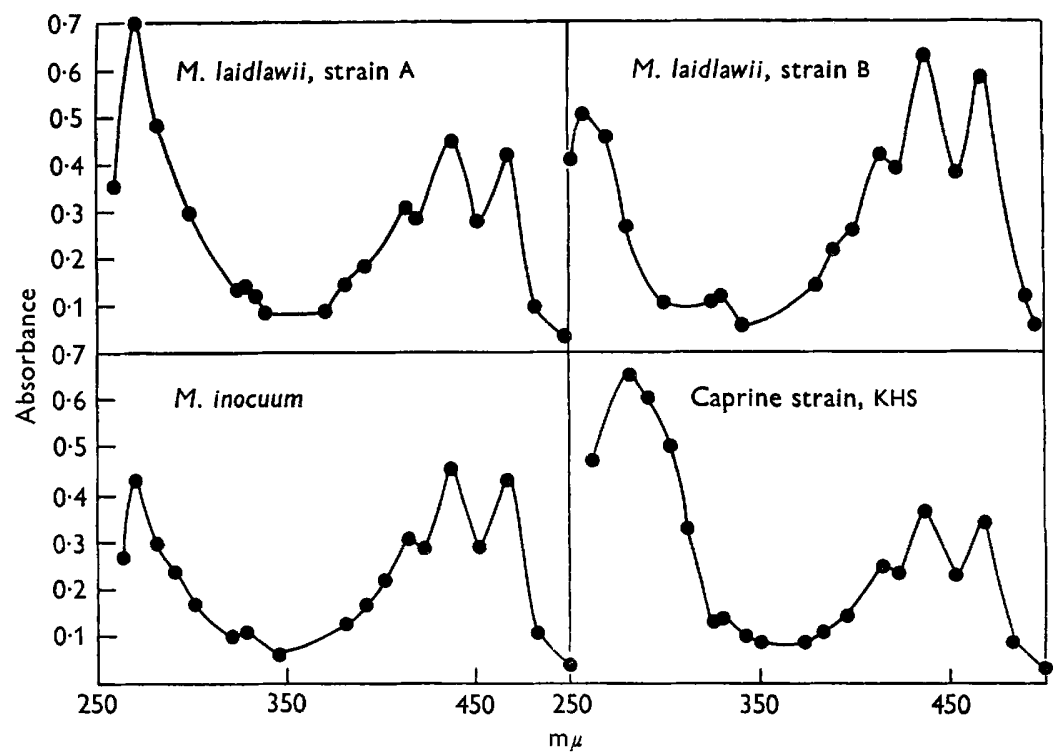

Fig. 1. Absorption spectra of the hydrocarbon carotenoid of Mycoplasma which do not require sterol as nutrient.

Table 4. Chemical and physical properties of hydrocarbon pigment $(A)$

\begin{tabular}{|c|c|c|c|c|}
\hline \multirow[b]{2}{*}{ Property } & \multicolumn{4}{|c|}{ Mycoplasma species } \\
\hline & M. laidlawii, & M. laidlawii, & M. inocuum & $\begin{array}{l}\text { Caprine } \\
\text { strain KHS }\end{array}$ \\
\hline $\begin{array}{l}\text { ion maxima } \\
\text { lexane) }\end{array}$ & $\begin{array}{l}275,414, \\
437,467\end{array}$ & $\begin{array}{l}258,414 \\
438,468\end{array}$ & $\begin{array}{l}272,414 \\
438,467\end{array}$ & $\begin{array}{l}273,414 \\
438,467\end{array}$ \\
\hline $438 \mathrm{~m} \mu$ & 2394 & 2968 & 1164 & 388 \\
\hline arr-Price) & + & + & + & + \\
\hline $\begin{array}{l}\mathrm{H}_{2} \mathrm{SO}_{4} \\
\mathrm{n} \text { : light }\end{array}$ & $\stackrel{+}{\text { Epiphasic }}$ & $\stackrel{+}{\text { Epiphasic }}$ & $\stackrel{+}{\text { Epiphasic }}$ & $\stackrel{+}{\text { Epiphasic }}$ \\
\hline
\end{tabular}

light petroleum (b.p. $30^{\circ}-60^{\circ}$ ) as developing solvent. Only one distinct band appeared which was eluted by $170 \mathrm{ml}$. of the solvent. It was concluded that pigment $\mathbf{A}$ was identical to neurosporene and consisted of the all trans isomer as indicated by the spectral shift upon iodine catalysed photoisomerization.

Pigment B from each of the organisms was also yellow in colour but distinctly less brilliant than pigment $\mathbf{A}$. It appeared as a more diffuse band with the eluting solvents used. Table 6 gives chemical and physical data for this pigment. In each case the pigment exhibited absorption maxima slightly lower than pigment $\mathbf{A}$, 
a shift common to carotenoids upon being oxygenated (Deuel, 1951). Pigment B was more polar than pigment $\mathbf{A}$ as indicated by its elution behaviour on silicic acid and its diffusiveness in both layers of the solvent partition mixture. Reaction with acetic- $1{ }^{14} \mathrm{C}$ anhydride in pyridine resulted in ready incorporation of radioactivity into the non-polar fraction, and saponification removed the radioactivity from the non-polar fraction. Acetylation resulted in the production of a salmon pink pigment

Table 5. Comparison of pigment $A$ from Mycoplasma laidlawii, strain в with authentic neurosporene

\begin{tabular}{|c|c|c|c|}
\hline Property & $\begin{array}{l}\text { Hydrocarbon } \\
\text { pigment (A) }\end{array}$ & Neurosporene & $\begin{array}{l}\text { Pigment } \mathbf{A +} \\
\text { neurosporene }\end{array}$ \\
\hline $\begin{array}{l}\text { Absorption maxima }(\mathrm{m} \mu) \\
\text { (hexane) }\end{array}$ & $417,441,472$ & $416,440,469$ & $417,440,470$ \\
\hline $\begin{array}{l}\text { Absorption minima }(\mathrm{m} \mu) \\
\text { (hexane) }\end{array}$ & 425,457 & 422,456 & 424,457 \\
\hline $\begin{array}{l}\text { Absorption maxima after } \\
\mathbf{I}_{2} \text { catalysis }(\mathrm{m} \mu) \text { (hexane) }\end{array}$ & $330,414,437,466$ & $333,414,438,465$ & n.d.* \\
\hline $\begin{array}{l}\text { Absorption minima after } \\
\mathbf{I}_{2} \text { catalysis }(\mathrm{m} \mu) \text { (hexane) }\end{array}$ & 422,453 & 422,455 & n.d. \\
\hline
\end{tabular}

Table 6. Chemical and physical properties of hydroxylated pigment $(\boldsymbol{B})$

\begin{tabular}{|c|c|c|c|c|}
\hline \multirow[b]{2}{*}{ Property } & \multicolumn{4}{|c|}{ Mycoplasma species } \\
\hline & $\begin{array}{l}\text { M. laidlarwii, } \\
\text { A }\end{array}$ & $\underset{\mathbf{B}}{\text { M. laidlareii, }}$ & M. inocuum & $\begin{array}{l}\text { Caprine } \\
\text { strain kHS }\end{array}$ \\
\hline $\begin{array}{l}\text { Absorption maxima }(\mathrm{m} \mu) \\
\text { (hexane) }\end{array}$ & $\begin{array}{l}272,404 \\
425,441\end{array}$ & $\begin{array}{l}-, 402 \\
422,446\end{array}$ & $\begin{array}{l}272,402 \\
424,440\end{array}$ & $\begin{array}{l}272,405 \\
424,440\end{array}$ \\
\hline$E_{1 \mathrm{~cm} .}^{1 \%}$ at $424 \mathrm{~m} \mu($ hexane $)$ & 263 & $\mathbf{3 4 8}$ & 161 & 64 \\
\hline $\mathrm{SbCl}_{3}$ (Carr-Price) & + & + & + & + \\
\hline $\begin{array}{l}\text { Partition: light } \\
\text { petroleum/methanol }\end{array}$ & $\begin{array}{c}\text { Epi- } \\
\text { hypophasic }\end{array}$ & $\begin{array}{c}\text { Epi- } \\
\text { hypophasic }\end{array}$ & $\begin{array}{c}\text { Epi- } \\
\text { hypophasic }\end{array}$ & $\begin{array}{c}\text { Epi- } \\
\text { hypophasic }\end{array}$ \\
\hline $\begin{array}{l}\text { Radioactivity after acetylatior } \\
\text { with acetic- } 1-{ }^{14} \mathrm{C}-\text { anhydride } \\
\text { (counts/min./mg. pigment): }\end{array}$ & 3144 & 1316 & 2344 & 1973 \\
\hline $\begin{array}{l}\text { Radioactivity after saponifica- } \\
\text { tion of acetylated pigment } \\
\text { (counts/min./mg. pigment) }\end{array}$ & 9 & 274 & 37 & 60 \\
\hline
\end{tabular}

which was eluted from silicic acid by benzene or $8 \%(\mathrm{v} / \mathrm{v})$ diethyl ether in light petroleum (b.p. $30^{\circ}-60^{\circ}$ ). Since pigment $B$ was capable of forming an ester with acetate, it was concluded that this pigment was an hydroxylated carotenoid. Iodine catalysis of pigment B from Mycoplasma laidlawii, strain B, resulted in the appearance of a cis peak and a spectral shift typical of all trans carotenoids, i.e. absorption maxima in hexane before catalysis were 402, 425, and $442 \mathrm{~m} \mu$; after catalysis, 356, 400, 423 and $440 \mathrm{~m} \mu$.

Two experiments were done to determine whether a relationship existed between the amount of pigment and the amount of acetate in ester linkage. The acetylated 
pigment of Mycoplasma laidlawii, strain B, purified by chromatography, was weighed and saponified. The non-aqueous phase was recovered and again weighed. The aqueous phase was steam distilled at $\mathbf{p H ~ 4}$, and titrated with standard alkali and acid. In one instance $0.86 \mathrm{mg}$. free pigment and $3.3 \mu$ mole acetate were recovered; in the other, $0.73 \mathrm{mg}$. free pigment and $2.8 \mu$ mole acetate. If it be assumed that the pigment was a dihydroxylated $\mathrm{C}-40$ carotenoid, its molecular weight would approximate $\mathbf{5 7 0}$ and the molar ratio of acetate to pigment would approximate 2. Such a molar relationship is valid only when pure pigments of assumed molecular weight are used. Nevertheless, these data suggest that the amount of acetate in ester form was not unreasonable as compared with the unacetylated material.

Table 7. Chemical and physical properties of naturally esterified pigment $\left(\boldsymbol{B}^{\prime}\right)$

\begin{tabular}{|c|c|c|c|c|}
\hline \multirow[b]{2}{*}{ Property } & \multicolumn{4}{|c|}{ Mycoplasma species } \\
\hline & $\underset{\mathbf{A}}{\text { M. laidlawii, }}$ & $\underset{\mathbf{B}}{\text { M. laidlarwii, }}$ & M. inocuum & $\begin{array}{l}\text { Caprine } \\
\text { strain KHS }\end{array}$ \\
\hline $\begin{array}{l}\text { Absorption maxima }(\mathrm{m} \mu) \\
\text { (hexane) }\end{array}$ & n..d & $\begin{array}{l}-, 402 \\
422,446\end{array}$ & $\begin{array}{l}272,405 \\
422,440\end{array}$ & n.d. \\
\hline$E_{1 \mathrm{~cm},}^{1 \%}$ at $422 \mathrm{~m} \mu$ (hexane) & n.d. & 97 & 73 & n.d. \\
\hline $\begin{array}{l}\text { Volatile fatty acids } \\
\text { (m equiv.)/non-volatile } \\
\text { fatty acids (m equiv.) }\end{array}$ & $\begin{array}{l}\text { Volatile } \\
\text { only }\end{array}$ & $2 \cdot 06$ & $0 \cdot 97$ & $3 \cdot 00$ \\
\hline Nature of volatile fatty acids & Acetic & Acetic & Acetic & Acetic \\
\hline
\end{tabular}

The detection of carotenols as components of the non-saponifiable lipid fractions of organisms not requiring sterol as nutrient lead to suspicion that carotenyl esters may occur naturally, analogous to the steryl esters of organisms requiring sterol as nutrient. The total lipid fraction of each of the four organisms was chromatographed as described. Pigment A was eluted with $2 \%(\mathrm{v} / \mathrm{v})$ benzene in light petroleum (b.p. $30^{\circ}-60^{\circ}$ ); pigment $\mathbf{B}^{\prime}$, the ester fraction, with $8 \%(\mathrm{v} / \mathrm{v})$ diethyl ether in light petroleum (b.p. $30^{\circ}-60^{\circ}$ ); pigment $B$ and pigment $C$ with the solvents previously mentioned. Pigment $\mathbf{B}^{\prime}$ appeared at the top of the column as a distinct salmon pink band but became diffuse and yellowish as it proceeded through the column. The analytical data on this pigment are given in Table 7 . The absorption spectra were identical with those of the free carotenols, but the absorption coefficients were decreased because of the greater molecular weight of the esters. The naturally occurring esters contained different amounts of volatile and non-volatile fatty acids as determined by titration. The significant finding was the presence of only acetic acid in the volatile fraction. No identification of the acids comprising the nonvolatile fraction was attempted. Non-volatile fatty acids could not be detected in the case of Mycoplasma laidlawii strain A.

Pigment $\mathrm{C}$ was the most polar of all the pigments. It remained adsorbed to the top of the column until diethyl ether was added as the eluting solvent. It appeared as a distinct brownish yellow band. Total recovery of this component from the saponification mixture required re-extraction of the aqueous layer with diethyl 
ether following the initial extraction with light petroleum. The absorption spectrum and a positive Carr-Price test indicated it to be a carotenoid pigment. Its behaviour during extraction procedures and on silicic acid columns bore a similarity to the cholesteryl glucoside present in glucose-fermenting Mycoplasma when supplied cholesterol in the growth medium. Hence this pigment was subjected to analytical techniques directed toward its probable identity as a glycoside of a carotenol. Table 8 presents the data.

Table 8. Chemical and physical properties of pigment glycoside $(C)$

\begin{tabular}{|c|c|c|c|c|}
\hline \multirow[b]{2}{*}{ Property } & \multicolumn{4}{|c|}{ Mycoplasma species } \\
\hline & M. laidlawii A & M. laidlawii $\mathrm{B}$ & M. inocuum & $\begin{array}{c}\text { Caprine } \\
\text { strain кHs }\end{array}$ \\
\hline $\begin{array}{l}\text { Absorption maxima }(\mathrm{m} \mu) \\
\text { (chloroform) }\end{array}$ & $411,433,451$ & $408,430,454$ & $406,430,452$ & $385,409,431$ \\
\hline$E\left(\begin{array}{l}1 \% \\
1 \mathrm{c} m\end{array}\right.$.chloroform $)$ & $93(433 \mathrm{~m} \mu)$ & $112(430 \mathrm{~m} \mu)$ & $52(430 \mathrm{~m} \mu)$ & $22(409 \mathrm{~m} \mu)$ \\
\hline $\mathrm{SbCl}_{3}$ (Carr-Price) & + & + & + & + \\
\hline $\begin{array}{l}\text { Partition : light } \\
\text { petroleum/methanol }\end{array}$ & Hypophasic & Hypophasic & Hypophasic & Hypophasic \\
\hline $\begin{array}{l}\text { Reducing sugar } \\
\text { (Park-Johnson) }\end{array}$ & + & + & + & + \\
\hline Action of $\beta$-glucosidase & + & + & + & + \\
\hline Enzymic test for glucose & + & + & + & + \\
\hline
\end{tabular}

Pigment $\mathbf{C}$ from all four organisms exhibited a plateau in the absorption curve between 280 and $290 \mathrm{~m} \mu$. The absorption coefficients are lower than those for the other pigments, again due to the greater molecular weight of the glycosides. The absorption coefficients of pigment $\mathrm{C}$, like those of pigment $\mathrm{B}$, are low and do not permit the relating of pigment $\mathrm{C}$ to neurosporene. Iodine-catalysed photoisomerization of pigment $\mathrm{C}$ from Mycoplasma laidlawii, strain $\mathrm{B}$, resulted in the appearance of a cis peak and a spectral shift typical of all trans carotenoids, i.e. the absorption maxima in chloroform before catalysis were 409, 433 and 454 $\mathrm{m} \mu$; after catalysis, 359, 402, 428 and $451 \mathrm{~m} \mu$. The pigment was polar, separating in the methanol phase of the solvent partition mixture. The aqueous fraction following acid hydrolysis gave a positive reaction for reducing sugar. No reducing sugar was detected in the unhydrolysed pigment. Alkaline hydrolysis was ineffective in cleaving the reducing sugar from the pigment. Acid hydrolysis destroyed the pigmented moiety thereby not permitting isolation and identification of the presumed carotenol portion. Pigment $\mathrm{C}$ of only two organisms, Mycoplasma laidlawii, strain B and $\boldsymbol{M}$. inocuum, was attacked by $\beta$-glucosidase to yield glucose detectable by the coupled hexokinase + glucose-6-phosphate dehydrogenase reaction. However, subjection of the neutralized water soluble fraction following acid hydrolysis of pigment $\mathrm{C}$ from $M$. laidlawii strain A and the caprine strain kHs to the action of hexokinase and glucose-6-phosphate dehydrogenase did result in reduction of NADP; Table 9 presents the data. The enzymic determination of glucose was complicated by the presence of contaminating glucose in the hexokinase preparation as evidenced by 
substantial reduction of NADP in the control containing no substrate. Nevertheless, NADP reduction in test samples was significantly greater than in the reagent control. It was concluded from this enzymic evidence that the reducing sugar was glucose. In the two organisms containing pigment $\mathrm{C}$ hydrolysable by $\beta$-glucosidase, this pigment was considered to be a carotenyl- $\beta$-glucoside. Although pigment $\mathrm{C}$ of the other two organisms contained glucose in obvious ether linkage, the isomeric structure could not be deduced from the data obtained.

\section{Table 9. Reduction of NADP by action of glucose-6-phosphate dehydrogenase on reducing sugar released from pigment $C$}

\begin{tabular}{|c|c|c|c|c|c|}
\hline \multirow[b]{2}{*}{$\begin{array}{l}\text { Time } \\
\text { (sec.) }\end{array}$} & \multirow[b]{2}{*}{ Control } & \multicolumn{4}{|c|}{ Mycoplasma species } \\
\hline & & $\underset{\mathrm{A}^{*}}{\text { M. laidlawii, }}$ & $\begin{array}{c}\text { M. laidlawii, } \\
\mathbf{B}^{\dagger}\end{array}$ & M. inocuum $\dagger$ & $\begin{array}{l}\text { Caprine* } \\
\text { strain KHS }\end{array}$ \\
\hline $0 \ddagger$ & $0 \cdot 000$ & $0 \cdot 015$ & $0 \cdot 010$ & $0 \cdot 015$ & 0.015 \\
\hline 60 & $0 \cdot 140 \S$ & $0 \cdot 480$ & $0 \cdot 347$ & $0 \cdot 220$ & $0 \cdot 370$ \\
\hline 90 & $0 \cdot 155$ & 0.565 & $0 \cdot 405$ & $0 \cdot 245$ & $0 \cdot 475$ \\
\hline 120 & $0 \cdot 165$ & $0 \cdot 638$ & $0 \cdot 432$ & $0 \cdot 260$ & 0.535 \\
\hline 150 & $0 \cdot 172$ & $0 \cdot 675$ & 0.452 & $0 \cdot 270$ & 0.570 \\
\hline 180 & $0 \cdot 180$ & $0 \cdot 703$ & $0 \cdot 480$ & 0.277 & $0 \cdot 605$ \\
\hline 600 & $0 \cdot 213$ & 0.900 & 0.515 & $0 \cdot 335$ & $0 \cdot 762$ \\
\hline \multicolumn{6}{|c|}{$\begin{array}{l}\text { * Reducing sugar released by acid hydrolysis. } \\
\dagger \text { Reducing sugar released by } \beta \text {-glucosidase. } \\
\text { † No glucose-6-phosphate dehydrogenase present. } \\
\S \text { Absorbance (optical density) at } \mathbf{3 4 0} \mathrm{m} \mu \text {. }\end{array}$} \\
\hline
\end{tabular}

A relationship between the amount of pigment $\mathrm{C}$ and the amount of glucose liberated by the action of $\beta$-glucosidase was shown with Mycoplasma laidlawii, strain B. Assuming complete utilization of substrate during the reaction, double the amount of lactose should yield the same value for glucose as the glucose control. These conditions were met by the test system, i.e. $4 \cdot 0 \mathrm{mg}$. lactose and $2 \cdot 0 \mathrm{mg}$. glucose gave final optical density readings of $0 \cdot 263$ and $0 \cdot 270$. Pigment $A$ in the amount of $7 \cdot 74 \mathrm{mg}$. yielded $2 \cdot 34 \mathrm{mg}$. glucose as calculated from optical density measurements. If it be assumed that the molecular weight of the pigment approximates that of a dihydroxylated $\mathrm{C}-\mathbf{4 0}$ carotenoid attached to glucose in ether linkage, i.e. about 750, and that complete hydrolysis occurred, the molar ratio of glucose found to pigment tested would approximate 1 .

Analysis of the chromatographic behaviour of pigment $\mathbf{C}$ from Mycoplasma laidlawii, strain $\mathrm{B}$, following the action of $\beta$-glucosidase was performed by extraction of the reaction mixture with light petroleum (b.p. $30^{\circ}-60^{\circ}$ ) and subjection of the extract to the same chromatographic procedure as used for the initial separation of the pigments. Two bands appeared, one eluting with the same solvent as pigment B, the other with the same solvent as pigment C. Re-chromatography of the less polar pigment mixed with pigment $\mathbf{B}$ resulted in the elution of one band. Further exposure of the more polar pigment to $\beta$-glucosidase resulted in additional formation of two pigments eluting as described above. Complete loss of pigment $\mathrm{C}$ as a 
result of the action of $\beta$-glucosidase was not achieved. However, only a small residual amount of this pigment remained even after the first exposure to $\beta$-glucosidase. Thus it appeared that $\beta$-glucosidase action on pigment $\mathrm{C}$ liberated a pigment with the same chromatographic behaviour as pigment B, an hydroxylated carotenoid.

\section{DISCUSSION}

The present work has shown the presence of three carotenoid pigments in the non-saponifiable lipid fractions of four non-sterol requiring Mycoplasma organisms. These pigments were synthesized by organisms which did not require sterol as nutrient and were not found in the sterol-requiring organisms. One pigment has been identified as a hydrocarbon carotenoid, similar to neurosporene. The other two pigments possess properties suggestive of an hydroxylated carotenoid and a carotenyl glucoside. Besides occurring in glycosidic linkage with glucose, the carotenol occurs naturally in ester linkage with fatty acids.

The absorption maxima of the hydrocarbon pigment of all four organisms are essentially identical. The absorption coefficients of pigments from Mycoplasma inocuum and the caprine strain KHS are considerably lower than those of $M$. laidlawii, strains A and B. It is not very probable that these lower absorption coefficients are the result of impure compounds since attempts to further fractionate any of the pigments yielded only one component.

The absorption coefficients of pigments $\mathrm{B}$ and $\mathrm{C}$ are too low to infer that these pigments are oxygenated derivatives of neurosporene. For example, the decrease in absorption coefficient as a result of oxygenation of $\beta$-carotene to zeaxanthin is about $15 \%$ (Deuel, 1951) while the difference between pigments $\mathrm{A}$ and $\mathrm{B}$ represents a $90 \%$ diminution. Such a wide difference would be explained by the presence of an impurity in pigments $\mathrm{B}$ and $\mathrm{C}$, by isomerization to a mixture of cis-trans isomers, or lack of similarity to neurosporene. Inability to separate pigments $\mathrm{B}$ and $\mathrm{C}$ into more than one component by gradient elution chromatography would suggest the absence of a major impurity or of contamination with other isomeric forms. The absence of a cis peak in these pigments prior to and the spectral shift following iodine-catalysed photoisomerization ruled out the possibility of their being a mixture of cis-trans isomers. Furthermore, isomerization does not result in reduction of absorption to the extent that it would explain the differences in absorption coefficients.

The major difficulty in characterizing all of the pigments detected was to obtain sufficient quantities for analysis. The small amounts obtained significantly affected the accuracy of the gravimetric determinations. Such errors would be magnified in the values calculated for absorption coefficients, thereby making these values less reliable than the other properties examined.

The carotenol as the free alcohol, esterified with fatty acids, and in glycosidic linkage with glucose is analogous to the free cholesterol, esterified cholesterol and the cholesteryl glucoside, found in organisms requiring sterol as nutrient and capable of fermenting glucose and in organisms not requiring sterol as nutrient supplied cholesterol in the growth medium (Rothblat \& Smith, 1961). The hydrocarbon carotenoid might be considered a precursor of the carotenol. Most naturally occurring carotenols possess hydroxyl groups on the 3 and 3' carbon atoms (Deuel, 1951). This position of the hydroxyl groups in carotenols is analogous to the position of the 
hydroxyl group in sterols, i.e. on carbon atom 3, capable of supporting growth of sterol-requiring organisms. Any enzymic activity vital to the organism and utilizing this 3-hydroxyl group presumably could function with a 3-hydroxy sterol or a 3-hydroxy carotenol because of the similarities of their molecular structures. Since some organisms are endowed with the enzymic pathway to synthesize a nonsaponifiable lipid of appropriate structure, they possess no requirement for 3-hydroxy sterol. On the other hand, those organisms incapable of synthesis of such compounds must be supplied with the preformed lipid.

A vital function for sterols in the sterol requiring organisms has been postulated to be substrate permeability (Smith, 1959; Smith, 1960; Rothblat \& Smith, 1961). The carotenols can be postulated to serve this same function in non-sterol-requiring strains, all of which contain the pigment. Thus a glucosidase could serve to transport glucose into the cell via the carotenyl glucoside. An esterase, demonstrated to be active against cholesteryl esters (Smith, 1959) could serve to transport the end product of glucose metabolism, acetate, via a carotenyl acetate, out of the cell. Additional support for this hypothesis is the location of the carotenoid pigments in the insoluble residue (cell membrane) following sonic lysis, and the finding that acetate is the only volatile fatty acid in ester linkage with the carotenol which occurs naturally in the organism. The presence of lipids with a molecular structure analogous to cholesterol in Mycoplasma which do not require sterol as nutrient substantiates a relationship between these organisms and the sterol-requiring Mycoplasma. In addition, the difference in the isomeric structure of the carotenyl glucosides of strains A and B of Mycoplasma laidlawii can lead to the presumption that the glucosidases of the two strains are different. This evidence adds credence to the distinction between the two strains.

This investigation was supported by a research grant, A 1-004410-01, from the Institute of Allergy and Infectious Diseases, U.S. Public Health Services.

\section{REFERENCES}

Adler, H. E., Shifrine, M. \& Ortmayer, H. (1961). Mycoplasma inocuum sp.n., a saprophyte from chickens. $J$. Bact. 82, 239.

DeuEl, H. J., Jun. (1951). The Lipids. I. Chemistry, pp. 396, 507. New York: Interscience Publishers, Inc.

Edward, D. G. FF. \& Freundt, E. A. (1956). The classification and nomenclature of organisms of the pleuropneumonia group. J. gen. Microbiol. 14, 197.

Hawk, P. B., Oser, B. L. \& Summerson, W. H. (1947). Practical Physiological Chemistry, p. 1041, 12th ed. Philadephia: The Blakiston Co.

Haxo, F. (1949). Studies on the carotenoid pigments of Neurospora. I. Composition of the pigment. Arch. Biochem. 20, 400.

Hirsch, J. \& Ahrens, E. H., Jun. (1958). The separation of complex lipid mixtures by the use of silicic acid chromatography. J. biol. Chem. 233, 311.

Magoon, E. F. \& Zechmeister, L. (1957). On a cis-neurosporene $e x$ Pyracantha and the in vitro stereoisomerization of neurosporene. Arch. Biochem. Biophys. 68, 263.

PARK, J. T. \& Johnson, M. J. (1949). A submicrodetermination of glucose. J. biol. Chem. $181,149$.

Reid, R. L. \& Lederer, M. (1951). Separation and estimation of saturated $\mathrm{C}_{2}-\mathrm{C}_{7}$ fatty acids by paper partition chromatography. Biochem. J. 50,60.

Rothblat, G. H. \& Smith, P. J. (1961). Nonsaponifiable lipids of representative pleuropneumonia-like organisms. J. Bact. 82, 479. 
Sмıтн, P.F. (1955). Amino acid metabolism by pleuropneumonia-like organisms. I. General catabolism. J. Bact. 70, 552.

Sмiтh, P. F. (1959). Cholesterol esterase activity of pleuropneumonia-like organisms. J. Bact. 77, 682.

Smith, P. F. (1960). Nutritional requirements of PPLO and their relation to metabolic function. Ann. N.Y. Acad. Sci. 79, 508.

Sмітн, P. F. (1962). Fate of ergosterol and cholestanol in pleuropneumonia-like organisms. J. Bact. 84, 534.

Sмith, P. F. \& Rothblat, G. H. (1960). Incorporation of cholesterol by pleuropneumonialike organisms. J. Bact. 80, 842.

Smith, P. F. \& Rothblat, G. H. (1962). Comparison of lipid composition of pleuropneumonia-like and L-type organisms. J. Bact. 83, 500.

SwIFT, L. J. (1952). Isolation of $\beta$-sitosteryl D-glucoside from the juice of Florida Valencia oranges (Citrus sinensis L.). J. Amer. chem. Soc. 74, 1099. 